University of Nebraska - Lincoln

DigitalCommons@University of Nebraska - Lincoln

Publications from USDA-ARS / UNL Faculty

U.S. Department of Agriculture: Agricultural

Research Service, Lincoln, Nebraska

2011

Switchgrass Leaf Area Index and Light Extinction Coefficients

Jim R. Kiniry

USDA-ARS, Jim.Kiniry@ars.usda.gov

Mari-Vaughn Johnson

USDA-ARS, mvjohnson@usgs.gov

Robert B. Mitchell

USDA-ARS, rob.mitchell@ars.usda.gov

Kenneth P. Vogel

University of Nebraska-Lincoln, kvogel1@unl.edu

Jerry Kaiser

USDA-NRCS

See next page for additional authors

Follow this and additional works at: https://digitalcommons.unl.edu/usdaarsfacpub

Kiniry, Jim R.; Johnson, Mari-Vaughn; Mitchell, Robert B.; Vogel, Kenneth P.; Kaiser, Jerry; Bruckerhoff, Steve; and Cordsiemon, Ron, "Switchgrass Leaf Area Index and Light Extinction Coefficients" (2011). Publications from USDA-ARS / UNL Faculty. 1955.

https://digitalcommons.unl.edu/usdaarsfacpub/1955

This Article is brought to you for free and open access by the U.S. Department of Agriculture: Agricultural Research Service, Lincoln, Nebraska at DigitalCommons@University of Nebraska - Lincoln. It has been accepted for inclusion in Publications from USDA-ARS / UNL Faculty by an authorized administrator of DigitalCommons@University of Nebraska - Lincoln. 


\section{Authors}

Jim R. Kiniry, Mari-Vaughn Johnson, Robert B. Mitchell, Kenneth P. Vogel, Jerry Kaiser, Steve Bruckerhoff, and Ron Cordsiemon 


\title{
Switchgrass Leaf Area Index and Light Extinction Coefficients
}

\author{
Jim Kiniry,* Mari-Vaughn Johnson, Robert Mitchell, Ken Vogel, \\ Jerry Kaiser, Steve Bruckerhoff, and Ron Cordsiemon
}

\begin{abstract}
Much of recent interest in biofuel species modeling has been for switchgrass (Panicum virgatum L.). Such modeling requires accurate simulation of light interception. We investigated the stability of the light extinction coefficient $(k)$ in Beer's Law with data from Temple, TX; Lincoln, NE; and Elsberry, MO. Variability in $k$ values was not related to fraction of light intercepted, time of day, or incident solar radiation. Only the magnitude of leaf area index (LAI) showed a significant impact on the $k$ value. The mean $k$ value $(-0.37)$ for the 'Alamo' switchgrass data at Temple was similar to the previously published $k$ value $(-0.33)$ and similar to Alamo $k$ values in Nebraska $(-0.38)$ and Missouri (-0.31). Compared to Alamo, other switchgrass cultivars had similar $k$ values in Nebraska but were higher in Missouri. This study gave guidance as to which factors are important for quantifying $k$ with Beer's Law for light interception of switchgrass.
\end{abstract}

Switchgrass is a North American native perennial bunchgrass (Hitchcock and Chase, 1971) commonly planted for forage, soil conservation, and wildlife habitat. Switchgrass is also one of the principal species being developed in the United States as a source of biomass for biofuel production (Sanderson et al., 2006). Switchgrass has been simulated at diverse sites in the United States (Brown et al., 2000; McLaughlin et al., 2006; Kiniry et al., 1996, 2005, 2008; Grassini et al., 2009). Such simulation studies often predict plant biomass based on radiation use efficiency (RUE), assuming, in the absence of stress, a stable value for amount of biomass produced per unit intercepted photosynthetically active radiation (IPAR). Thus, once canopy level LAI is determined, IPAR can be predicted with Beer's Law (Monsi and Saeki, 1953) using a single derived constant, the light extinction coefficient $(k)$. Plants with more upright leaf angles have lower $k$ values, allowing greater light penetration into canopies.

While the simplicity of the Beer's Law approach makes it attractive for simulating biomass yield for a given species, there are potential problems with it that may lead to inaccurate simulations. Possible sources of error in predicting light interception with Beer's Law include: (i) light conditions; (ii) solar angle; (iii) plant spacing; or (iv) variable plant architecture within a species, possibly due to physiological variation between different cultivars. Consideration of these variables has been

J. Kiniry, USDA-ARS, Grassland, Soil and Water Research Center, 808 E Blackland Rd., Temple, TX 76502; M.-V. Johnson, USDA-ARS, Univ. of Nebraska-Lincoln, Lincoln, NE 68583; R. Mitchell and K. Vogel, USDAARS, 808 E. Blackland Rd, Temple, TX 76502; J. Kaiser, S. Bruckerhoff, and R. Cordsiemon, USDA-NRCS, Elsberry Plant Materials Center, 2803 N. Hwy 79, Elsberry, MO 63343. Received 17 June 2010. * Corresponding author (jim.kiniry@ars.usda.gov).

Published in Agron. J. 103:119-122 (2011)

Published online 22 Nov 2010

doi: 10.2134/agronj2010.0280

Copyright (C) 2011 by the American Society of Agronomy, 5585 Guilford Road, Madison, WI 53711. All rights reserved. No part of this periodical may be reproduced or transmitted in any form or by any means, electronic or mechanical, including photocopying, recording, or any information storage and retrieval system, without permission in writing from the publisher. the impetus for the development of numerous, more detailed systems of simulating light interception and plant response (Sinoquet and Bonhomme, 1989; Varlet-Grancher et al., 1989; Goward and Huemmrich, 1992; Maddonni et al., 2001; Drouet, 2003). However, before abandoning Beer's Law in favor of more complicated modeling systems, it would be helpful to know the relative importance of various sources of error in the predictions of fraction of intercepted photosynthetically active radiation (FIPAR) with Beer's Law. It is possible a simple correction factor could be employed in conjunction with Beer's Law in lieu of adopting more complicated models.

With this in mind, the objective of this study was to quantify the impact of (i) LAI, (ii) FIPAR, (iii) time of day, (iv) light intensity (especially as related to direct vs. diffuse light), and (v) physiological variation by cultivar on variability of $k$ in Beer's Law. Data used included measurements of 'Alamo' switchgrass at Temple, TX measurements of northern switchgrass cultivars at Elsberry, MO and at Mead, NE. These results are especially relevant as simulation models such as ALMANAC (Kiniry et al., 1992) and EPIC (Williams et al., 1984) are applied to sites and cultivars outside their original validations in Texas. As planting of switchgrass cultivars in large tracts outside of their original range becomes more common, modeling biomass yields with accuracy will continue to gain in importance so that the optimal cultivar for a given site can be chosen. Understanding the physiological processes that determine yield is relevant not only to modeling efforts, but also to future breeding efforts (Vargas et al., 2002).

\section{MATERIALS AND METHODS}

The data set for the first part of the meta-analysis (Analysis I) consisted of measurements on 56 dates over several years on established plots of 'Alamo' switchgrass at the USDA-ARS Grassland, Soil and Water Research Laboratory in Temple, TX $\left(31^{\circ} 4^{\prime} \mathrm{N} 97^{\circ} 13^{\prime} \mathrm{W}\right)$. Some of these data were presented in

Abbreviations: FIPAR, fraction of photosynthetically active radiation intercepted by the plant canopy; IPAR, intercepted photosynthetically active radiation; $k$, extinction coefficient for Beer's Law; LAI, leaf area index; PAR, photosynthetically active radiation; RUE, radiation use efficiency. 
Kiniry et al. (1999) and Kiniry et al. (2007). Additional sets of measurements were taken at the University of Nebraska Agricultural Research and Development Center (ARDC) which is located about $70 \mathrm{~km}$ northeast of Lincoln, NE near the small town of Mead, NE (41. $\left.13^{\prime} 34^{\prime} \mathrm{N} 96^{\circ} 29^{\prime} 18^{\prime} \mathrm{W}\right)$ in 2008 for cultivars of switchgrass including Alamo, 'Kanlow', 'CaveIn-Rock', 'Shawnee', and a 'Kanlow' × 'Summer' population. In 2008, measurements were also taken at the USDA-NRCS Plant Materials Center at Elsberry, MO (39¹0'09' N, 9047'13' W) on Alamo, Kanlow, and Cave-In-Rock switchgrass cultivars. Soil types at the three locations were: Houston Black clay (fine, smectitic, thermic Udic Haplusterts) at Temple; Sharpsburg silt loam (fine, smectitic, mesic Typic Argiudolls) at Mead; and Haymond silt loam (coarse-silty, mixed, superactive, mesic Dystric Fluventic Eutrudepts) at Elsberry. Switchgrass plots at Temple were established in 1993 and first measured in 1995. Plots at Mead were established in 2002 and measured in 2008. Plots at Elsberry were established in 2007 and measured in 2008.

On all dates, direct measurements of FIPAR were taken and actual LAI was determined using destructive sampling. The corresponding $k$ values were derived and cases for $k$ variability were investigated. In the earlier years' measurements, three sets of PAR measurements were taken in quick succession $10 \mathrm{~cm}$ above the ground surface, under each species canopy, and in the open using a $0.8-\mathrm{m}$ long Sunflect Ceptometer (Decagon Devices Inc., Pullman, WA) to enable calculation of fraction of light transmitted through the leaf canopy. In the latter years, an external sensor was used to take concurrent above and below $\mathrm{PAR}$ readings, an even more efficient technique. The value of FIPAR was calculated as 1.0 - (PAR below)/(PAR above). Aboveground plant material from $1 \mathrm{~m}^{2}$ of ground area $\left(0.5 \mathrm{~m}^{2}\right.$ at Elsberry) was collected and the fresh weight was recorded. A representative subset of tillers was weighed fresh and LAI was determined for green leaves and green stems with a LiCor LI3100 leaf area meter (LiCor Inc., Lincoln, NE). None of these plants were drought stressed to the point that leaves were rolling. Senesced leaf material was weighed and determined to be an inconsequential fraction of the total leaf area. Thus this senesced leaf material was not considered for the LAI calculations. Likewise, panicles comprised an inconsequential fraction of the total plant area (including leaves and stems), so were not considered in these analyses. An LAI value (including green leaves and green stems) for the stand was calculated as the area of the subsample times the ratio of the total fresh weight/ subsample fresh weight divided by sampled ground area. The $k$ value was calculated by changing the equation

$$
\text { FIPAR }=1.0-\exp (k \times \text { LAI })
$$

into

$$
k=\left[\log _{\mathrm{n}}[1.0-\mathrm{FIPAR}]\right] / \mathrm{LAI}
$$

In Analysis I, using the Alamo switchgrass data at Temple, we examined effects of LAI, FIPAR, time of day, and incident solar radiation on $k$. Since these variables were all continuous, regression analysis was used throughout. Separate analyses were conducted looking at each of four effects. The $k$ values were regressed on each of these variables, with the resulting $r^{2}$ and
$P$ value for the slopes examined for significance. These gave an indication as to the value of each variable in accounting for the variability in measured $k$ values. We used the $95 \%$ level for significance for all analyses.

In the Analysis II portion of our meta-analysis, using the multiple genotype measurements at Mead and Elsberry, we compared other genotypes' $k$ values to Alamo's mean $k$ at Temple. This gave some indication of the applicability of using Alamo's mean $k$ to simulate other switchgrass cultivars.

\section{RESULTS}

\section{Multi-year Alamo Switchgrass Data at Temple, $\mathbf{T X}$}

The mean $k$ value for the pooled Temple Alamo switchgrass data set was similar to the first Alamo $k$ value we published (-0.33; Kiniry et al., 1999). The 56 data points of Alamo at Temple had a $\bar{x} \pm$ SD for $k$ of $-0.37 \pm 0.18$. The LAI (comprised of green leaves and green stems, taken on different dates in several growing seasons) of these measurements ranged from 0.1 to 26.1 ( $\bar{x}=5.88$ ), and FIPAR ranged from 0.14 to 0.99 $(\bar{x}=0.69)$.

The $k$ values were significantly $(P=0.001)$ related to the LAI values, but only accounted for $18 \%$ of the variability in $k$. The slope indicated that $k$ decreased in magnitude ( $k$ is negative) with increasing LAI. The regression equation was:

$$
k=0.02 \mathrm{LAI}-0.46, r^{2}=0.18, \text { slope } P \text { value }=0.001
$$

Data was split into two groups at LAI values corresponding to approximately $90 \%$ FIPAR. Using the mean $k$ value -0.37 , this break point was $\mathrm{LAI}=6.19$. The LAI values above this break point tended to have lower absolute values of $k$.

For LAI $<6.19, \bar{x} \pm \mathrm{SD}$ for $k$ was $-0.42 \pm 0.19$

For LAI $>6.19, \bar{x} \pm \mathrm{SD}$ for $k$ was $-0.26 \pm 0.08$

Therefore, when LAI was below values for near-complete light interception (and thus minimal mutual leaf shading within the canopies), the leaf canopy was more efficient in intercepting light, as evidenced by the larger $k$ value.

In contrast, the FIPAR values had no significant effect in accounting for variability in $k$. The regression equation was:

$$
k=0.017 \text { FIPAR }-0.384, r^{2}=0.0006, \text { slope } P \text { value }=0.86[4]
$$

When split into two data groups, using FIPAR $=0.90$ as the point of division, there was no difference between mean $k$ below as compared to above 0.90 FIPAR.

For FIPAR $\leq 0.90, \bar{x} \pm$ SD for $k$ was $-0.372 \pm 0.17$

For FIPAR $>0.90, \bar{x} \pm$ SD for $k$ was $-0.373 \pm 0.19$

Time of day did not contribute to the observed variability in $k$ values. The regression equation was: 
Table I. Mean $k$ values when measurements were sorted by time of day for Alamo switchgrass at Temple, TX.

\begin{tabular}{lcc}
\hline \multicolumn{1}{c}{ Times, $\mathbf{h}$} & Mean $\boldsymbol{k}$ & $\mathbf{n}$ \\
\hline $0800-0859$ & -0.34 & 4 \\
$0900-0959$ & -0.47 & $\mathrm{I}$ \\
$1000-1059$ & -0.43 & 14 \\
$1100-1159$ & -0.35 & 18 \\
$1200-1259$ & -0.34 & 9 \\
$1300-1359$ & -0.34 & 8 \\
$\mid 400-1459$ & -0.39 & 2 \\
\hline
\end{tabular}

$k=0.301$ FIPAR $-0.516, r^{2}=0.009$, slope $P$ value $=0.484[5]$

When data was split into groups by increments of $1 \mathrm{~h}$ (Table 1), there was no obvious trend for $k$ with time of day.

Mean incident light levels (PAR) did not contribute to the observed variability in $k$ values. The regression equation was:

$$
k=0.000054 \mathrm{PAR}-0.45, r^{2}=0.053 \text {, slope } P \text { value }=0.087[6]
$$

When solar data were split into groups by increments of $50010^{4} \mu \mathrm{mol} \mathrm{m}^{-2} \mathrm{~s}^{-1}$ (Table 2) there was no obvious trend for $k$ with PAR.

\section{Single Date Measurements at Two Sites with Different Cultivars}

The Alamo $k$ values at Mead (-0.31) and Elsberry $(-0.38)$ (Table 3) were similar to the mean $k$ value at Temple $(-0.37)$. Alamo LAI values at Elsberry (8.5) and Mead (12.0) were similar to those measured at Temple (means ranged from 11-18).

The $k$ and LAI values of other switchgrass cultivars were not as consistent as these values for Alamo across both sites (Table 3). At Elsberry, LAI values of switchgrass cultivars Kanlow (4.8) and Cave-In-Rock (2.9) were lower than Alamo (8.5) At Elsberry, $k$ values of switchgrass cultivars Kanlow (-0.67) and Cave-in-Rock $(-1.11)$ were higher than were Alamo $k$ values at Elsberrry $(-0.38)$ or Temple (-0.37). At Mead, $k$ values for all switchgrass cultivars, including Alamo, were consistently low $(-0.23$ to -0.36$)$, similar to $k$ values for Alamo at Temple. The LAI values at Mead for the other switchgrass cultivars were high, with means of 10 to 22, comparable to Alamo means at Temple (11 to 18).

\section{DISCUSSION}

We conclude that using a stable value for $k$ in Beer's law for switchgrass is superior to attempting to introduce more complex calculations of $k$, allowing it to vary with LAI, time-of-day, or between cloudy and clear sky conditions. In other words, more complex systems, incorporating some of the variables we investigated herein, are not worth the extra effort in that they will not increase simulation accuracy noticeably. Future studies including sensitivity analysis could show the advantages or lack of advantages of such complex, data-hungry systems, in light of the natural variability present in such grass production systems. It is likely, in our opinion, that such analyses would find Beer's Law quite adequate for simulating biofuel perennial grass systems such as switchgrass.

While Beer's Law based simulations are not perfect, more detailed approaches that attempt to mathematically account for effects of FIPAR, time of day, or PAR, do not appear to be worth the more complicated calculations and extra time required to collect the more detailed inputs. In Analysis I, only the magnitude
Table 2. Mean $k$ values when sorted by incident solar radiation for Alamo switchgrass at Temple, TX.

\begin{tabular}{lcr}
\hline \multicolumn{1}{c}{ Mean incident light } & Mean $\mathbf{k}$ & $\boldsymbol{n}$ \\
\hline \multicolumn{1}{c}{$10^{4} \mu \mathrm{mol} \mathrm{m} \mathrm{m}^{-2} \mathrm{~s}^{-1}$} & & \\
$0-500$ & -0.37 & 7 \\
$500-1000$ & -0.44 & 15 \\
$1000-1500$ & -0.41 & 6 \\
$1500-2000$ & -0.35 & 16 \\
$2000-2500$ & -0.27 & 8 \\
$2500-3000$ & -0.36 & 3 \\
$3000-3500$ & -0.33 & 1 \\
\hline
\end{tabular}

Table 3. Leaf area index (LAI) and $k$ values (Mean \pm SD) for different switchgrass cultivars at two locations measured in 2008.

\begin{tabular}{|c|c|c|c|}
\hline \multirow{2}{*}{$\begin{array}{l}\text { Switchgrass } \\
\text { cultivar }\end{array}$} & \multicolumn{2}{|c|}{ Elsberry, MO } & Mead, NE \\
\hline & LAI & $k$ & LAI \\
\hline Alamo & $8.5 \pm 1.6$ & $-0.38 \pm 0.10$ & $|2.0 \pm 5.4-0.3| \pm 0.13$ \\
\hline Kanlow & $4.8 \pm 1.7$ & $-0.67 \pm 0.31$ & $22.0 \pm 5.6-0.23 \pm 0.06$ \\
\hline Cave-In-Rock & $2.9 \pm 0.9$ & $-1.11 \pm 0.31$ & $10.1 \pm 2.9-0.36 \pm 0.15$ \\
\hline Summer & & & $11.0 \pm 1.0-0.27 \pm 0.14$ \\
\hline Shawnee & & & $15.5 \pm 5.9-0.29 \pm 0.12$ \\
\hline Kanlow $\times$ Summer & & & $13.1 \pm 2.0-0.28 \pm 0.04$ \\
\hline
\end{tabular}

of LAI showed a significant impact on the $k$ value. However even LAI only accounted for a small fraction of the variability in $k$ (18\%). This suggests that future research should consider other possible factors that may affect switchgrass $k$, such as plant spacing.

In addition, Analysis II demonstrated that there was little difference among cultivars of switchgrass in their mean $k$ values when comparing Temple, TX and Mead, NE. Looking at the results from Temple and Mead, using Beer's Law and a $k$ value of -0.31 to -0.37 , one can realistically simulate values for summed IPAR for any of the switchgrass cultivars we measured. The lower LAI results for Elsberry (and correspondingly relatively high $k$ values) need to be interpreted with care, as data were collected during the first year following establishment. At the other two sites, measurements were on plots established for at least $2 \mathrm{yr}$. Future research should explore whether stand age could affect $k$ values of Beer's Law.

Work in Montreal, Canada on various cultivars of switchgrass in 2-yr-old plots for $2 \mathrm{yr}$ showed average LAI values of 5.1 for Summer, 6.1 for Cave-in-Rock, and 5.3 for Pathfinder, with $k$ values of $-0.49,-0.54$, and -0.54 , respectively (Madakadze et al., 1998). We did not consider the latitude of origin for the various cultivars as a factor that might affect $k$ or LAI values. However, we did not find that LAI and $k$ values appeared to vary by cultivar of switchgrass. Cultivar $\times$ environment interactions have been observed affecting various phenological traits, tissue composition, tissue allocation, survivorship, and overall yield (Hopkins et al., 1995a, 1995b; Sanderson et al., 1999; Casler et al., 2004; Berdahl et al., 2005; Casler et al., 2007), but LAI and $k$ were not explored in these studies. We suggest future genotype $\times$ environment studies should include effects on LAI and $k$.

\section{REFERENCES}

Berdahl, J.D., A.B. Frank, J.M. Krupinsky, P.M. Carr, J.D. Hanson, and H.A. Johnson. 2005. Biomass yield, phenology, and survival of diverse switchgrass cultivars and experimental strains in Western North Dakota. Agron.J.97:549-555.

Brown, R.A., N.J. Rosenberg, C.J. Hays, W.E. Easterling, and L.O. Mearns. 2000. Potential production and environmental effects of switchgrass and traditional crops under current and greenhouse-altered climate in the central United States: A simulation study. Agric. Ecosyst. Environ. 78:31-47. 
Casler, M.D., K.P. Vogel, C.M. Taliaferro, N.J.Ehlke,J.D. Berdahl, E.C. Brummer, R.L. Kallenbach, C.P. West, and R.B. Mitchell. 2007. Latitudinal and longitudinal adaptation of switchgrass populations. Crop Sci. 47:2249-2260.

Casler, M.D., K.P. Vogel, C.M. Taliaferro, and R.L. Wynia. 2004. Latitudinal adaptation of switchgrass populations. Crop Sci. 44:293-303.

Drouet, J.-L. 2003. MODICA and MODANCA: Modeling the three-dimensional shoot structure of graminaceous crops from two methods of plant description. Field Crops Res. 83:215-222.

Goward, S.N., and K.F. Huemmrich. 1992. Vegetation canopy PAR absorptance and normalized difference vegetation index: An assessment using the SAIL model. Remote Sens. Environ. 39:131-140.

Grassini, P., P.E. Hunt, R.B. Mitchell, and A. Weiss. 2009. Simulating switchgrass growth and development under potential water-limiting conditions. Agron. J. 101:564-571.

Hitchcock, A.S., and A. Chase. 1971. Manual of the grasses of the United States. Misc. Publ. 200. USDA, Washington, DC.

Hopkins, A.A., K.P. Vogel, K.J. Moore, K.D. Johnson, and I.T. Carlson. 1995a. Genotype effects and genotype by environment interactions for the traits of elite switchgrass populations. Crop Sci. 35:125-132.

Hopkins, A.A., K.P. Vogel, K.J. Moore, K.D. Johnson, and I.T. Carlson. 1995b. Genotypic variability and genotype $\times$ environment interactions among switchgrass accessions from the Midwestern USA. Crop Sci. 35:565-571.

Kiniry, J.R., B.L. Burson, G.W. Evers, J.R. Williams, H. Sanchez, C. Wade, J.W. Featherston, and J. Greenwade. 2007. Coastal bermudagrass, bahiagrass, and native range simulation at diverse sites in Texas. Agron. J. 99:450-461.

Kiniry, J.R., K.A. Cassida, M.A. Hussey, J.P. Muir, W.R. Ocumpaugh, J.C. Read, R.L. Reed, M.A. Sanderson, B.C. Venuto, and J.R. Williams. 2005. Switchgrass simulation by the ALMANAC model at diverse sites in the southern U.S. Biomass Bioenergy 29:419-425.

Kiniry, J.R., M.A. Sanderson, J.R. Williams, C.R. Tischler, M.A. Hussey, W.R. Ocumpaugh, J.C. Read, G. Van Esbroeck, and R.L. Reed. 1996. Simulating Alamo switchgrass with the ALMANAC model. Agron. J. 88:602-606.

Kiniry, J.R., M.R. Schmer, K.P. Vogel, and R. Mitchell. 2008. Switchgrass biomass simulation at diverse sites in the northern Great Plains of the U.S. Bioenergy Res. 1:259-264.
Kiniry, J.R., C.R. Tischler, and G.A. Van Esbroech. 1999. Radiation use efficiency and leaf $\mathrm{CO}_{2}$ exchange for diverse $\mathrm{C}_{4}$ grasses. Biomass Bioenergy 17:95-112.

Kiniry, J.R., J.R. Williams, P.W. Gassman, and P. Debaeke. 1992. A general, processoriented model for two competing plant species. Trans. ASAE 35:801-810.

Madakadze, I.C., K. Stewart, P.R. Peterson, B.E. Coulman, R. Samson, and D.L. Smith. 1998. Light interception, use-efficiency, and energy yield of switchgrass (Panicum virgatum L.) grown in a short season area. Biomass Bioenergy 15:475-482.

Maddonni, G.A., M. Chelle, J.-L. Drouet, and B. Andrieu. 2001. Light interception of contrasting azimuth canopies under square and rectangular plant spatial distributions: Simulations and crop measurements. Field Crops Res. 70:1-13.

McLaughlin, S.B., J.R. Kiniry, C.M. Taliaferro, and D. De LaTorre Ugarte. 2006. Projecting yield and utilization potential of switchgrass as an energy crop. Adv. Agron. 90:267-297.

Monsi, M., and T. Saeki. 1953. Über den lichtfaktor in den pflanzengesellschaften und seine bedeutung fur die stoffproduktion. Jpn. J. Bot. 14:22-52.

Sanderson, M.A., P.R. Adler, A.A. Boateng, M.D. Casler, and G. Sarath. 2006. Switchgrass as a biofuels feedstock in the USA. Can.J. Plant Sci. 86:1315-1325.

Sanderson, M.A., R.L. Reed, W. L. Ocumpaugh, M.A. Hussey, G. Van Esbroeck, J.C. Read, C.R. Tischler, and F.M. Hons. 1999. Switchgrass cultivars and germplasm for biomass feedstock production in Texas. Bioresour. Technol. 67:209-219.

Sinoquet, H., and R. Bonhomme. 1989. Modelling of solar radiation interception in row crops. II. Crop geometry and validation of the model. Agronomie 9:619-628.

Vargas, L.A., M.N. Anderson, C.R. Jensen, and U. Jøgensen. 2002. Estimation of leaf area index, light interception and biomass accumulation of Miscanthus sinensis "Goliath" from radiation measurements. Biomass \& Bioenergy 22:1-14.

Varlet-Grancher, C., G. Gosse, M. Chartier, H. Sinoquet, R. Bonhomme, and J.-M. Allirand. 1989. Solar radiation absorbed or intercepted by a crop. Agronomie 9:429-439.

Williams, J.R., C.A. Jones, and P.T. Dyke. 1984. A modeling approach to determining the relationship between erosion and soil productivity. Trans. ASAE 27:129-144. 